\title{
Effects of Paclobutrazol on Cadmium Accumulation of Stellaria Media
}

\author{
Jiajing Huang ${ }^{1, a}$, Lijin Lin ${ }^{2, b}$, Lei Yuan ${ }^{1, c}$, and Ming'an Liao ${ }^{1, d^{*}}$ \\ ${ }^{1}$ College of Horticulture, Sichuan Agricultural University, Chengdu, China \\ ${ }^{2}$ Institute of Pomology and Olericulture, Sichuan Agricultural University, Chengdu, China \\ a2298842195@qq.com, 'llj800924@163.com, '605862190@qq.com, Iman@sicau.edu.cn \\ ${ }^{*}$ Corresponding author, Jiajing Huang, Lijin Lin and Lei Yuan contributed equally to this work.
}

\begin{abstract}
Keywords: Paclobutrazol (PP333); Cadmium accumulation; Stellaria media; Growth
Abstract: The effects of paclobutrazol (PP333) on cadmium (Cd) accumulation of Stellaria media were investigated through a pot experiment. The results showed that the root biomass increased with the increase of PP333 concentrations, but the shoot biomass and total biomass decreased. PP333 enhanced the photosynthetic pigment content, antioxidant enzyme activity and soluble protein content of $S$. media, and decreased the soluble sugar content in shoots of $S$. media. The low concentrations of PP333 (25 and $50 \mathrm{mg} / \mathrm{L})$ increased the Cd content in roots of S. media, and high concentrations of PP333 (100 and $200 \mathrm{mg} / \mathrm{L}$ ) decreased that. The Cd content in shoots increased when applied the treatments of PP333. When applied PP333 on S. media, the Cd accumulation amount of roots was higher than the control, and the $\mathrm{Cd}$ accumulation amount of shoots and whole plants were lower than the control. Therefore, PP333 could not improve the phytoremediation ability of S. media.
\end{abstract}

\section{Introduction}

The paclobutrazol (PP333) is a plant growth regulator, which belongs to the plant growth retardants [1]. For common plants, PP333 promotes the growth of maize seedlings, and reduces the heavy metals in plants, which improves the tolerance of maize seedlings to heavy metals [2]. PP333 also promotes the growth of sweet sorghum seedlings under copper stress, and reduces the absorption of copper [3]. For heavy metal hyperaccumulator plants, PP333 improves the chromium accumulation ability of Houttuynia cordata Thunb, and enhances the resistance of plant to chromium [4]. Therefore, the application of PP333 could decrease the heavy metal concentration in common plants, and increase the heavy metal concentration in hyperaccumulator plants.

Stellaria media is a widely distributed Cd-accumulator plant [5]. In this study, we used the different concentrations of PP333 to treat S. media, and studied the effects of PP333 on growth and cadmium (Cd) accumulation of S. media. The aim of the study was to screen the best PP333 concentration which could enhance the phytoremediation ability of $S$. media, and provided a reference for applying the plant hormones on other hyperaccumulators or accumulators for improving their phytoremediation ability.

\section{Materials and Methods}

Materials. The soil samples used in the experiment were inceptisol soil, which were collected from the Ya'an campus farm of Sichuan Agricultural University $\left(29^{\circ} 59^{\prime} \mathrm{N}, 102^{\circ} 59^{\prime} \mathrm{E}\right)$ in August 2014. The basic properties of the soil, total $\mathrm{Cd}$ content and available $\mathrm{Cd}$ content in soil are described in the reference of Lin et al. (2014) [6]. The $S$. media seedlings with height of $10 \mathrm{~cm}$ were collected from the Ya'an campus farm in October 2014.

Experimental Design. The soil samples were air-dried and passed through a 5-mm sieve. Four kilograms of the air-dried soil was weighed into each polyethylene pot $(18 \mathrm{~cm}$ high, $21 \mathrm{~cm}$ in diameter). Cd was added to soils as $\mathrm{CdCl}_{2} \cdot 2.5 \mathrm{H}_{2} \mathrm{O}$ at $25 \mathrm{mg} / \mathrm{kg}$ in August 2014, and the soil moisture was maintained at $80 \%$ of field capacity for 2 months. Four uniform S. media seedlings were transplanted into each pot in October 2014, and watered every day to keep the soil moisture content 
maintaining at $80 \%$ of field capacity. When S. media seedlings grow one month (November 2014) in Cd contaminated soil, 5 concentrations $(0,25,50,100$ and $200 \mathrm{mg} / \mathrm{L})$ of PP333 with 4 replicates were sprayed on the leaves of plants for each pot, respectively. The amount of each pot was $25 \mathrm{ml}$ of PP333 solution. After PP333 treatment one month (December 2014), the upper mature leaves of S. media were collected to determine the photosynthetic pigment (chlorophyll $a$, chlorophyll $b$, total chlorophyll and carotenoid) contents [7]. The upper young shoots $(2 \mathrm{~cm}$ in length) were collected to determine the superoxide dismutase (SOD) activity, peroxidase (POD) activity, catalase (CAT) activity and soluble protein content [7]. Then, the whole plants were then gently removed from the soil. The treatments of plants are described in the reference of Lin et al. (2014) [6]. The Cd concentrations in roots and shoots were determined using an iCAP 6300 ICP spectrometer (Thermo Scientific, Waltham, MA, USA). The soluble sugar contents in shoots of $S$. media were determined by anthrone colorimetry with dry weight plant samples [7].

Statistical Analyses. Statistical analyses were conducted using SPSS 13.0 statistical software (IBM, Chicago, IL, USA). Data were analyzed by one-way analysis of variance with least significant difference (LSD) at the $p=0.05$ confidence level. Root/ shoot ratio $=$ root biomass/ shoot biomass [8], the resistance coefficient $=$ total biomass of treatment group/ control group [9], the bioconcentration factor $(\mathrm{BCF})=\mathrm{Cd}$ content in roots (shoots) $/ \mathrm{Cd}$ concentration in soil [10], the translocation factor $(\mathrm{TF})$ $=\mathrm{Cd}$ content in shoots $/ \mathrm{Cd}$ content in roots [11], the transfer amount factor $(\mathrm{TAF})=(\mathrm{Cd}$ content in shoots $\times$ shoot biomass $) /($ Cd content in roots $\times$ root biomass $)[12]$.

\section{Results and Discussion}

Biomass of $S$. media. With the increase of PP333 concentrations, the root biomass of S. media increased, but the shoot biomass decreased (Table 1). The whole plant biomass of $S$. media decreased with the increase of PP333 concentrations. At 25, 50, 100 and $200 \mathrm{mg} / \mathrm{L} \mathrm{PP333,} \mathrm{the} \mathrm{shoot} \mathrm{biomass}$ decreased by $31.75 \%(p<0.05), 44.51 \%(p<0.05), 46.57 \%(p<0.05)$ and $50.70 \%(p<0.05)$ respectively, compared with the control. The root/ shoot ratio increased with the increase of PP333 concentrations, and the resistance coefficient had the trend of decreasing (Table 1). So, PP333 inhibited the growth of $S$. media, but promoted the root growth of $S$. media.

\section{Table 1 Effects of PP333 on biomass of $S$. media}

\begin{tabular}{|c|c|c|c|c|c|}
\hline $\begin{array}{c}\text { PP333 concentration } \\
(\mathrm{mg} / \mathrm{L})\end{array}$ & $\begin{array}{c}\text { Roots } \\
(\mathrm{g} / \text { plant })\end{array}$ & $\begin{array}{c}\text { Shoots } \\
\text { (g/plant) }\end{array}$ & $\begin{array}{c}\text { Whole plants } \\
\text { (g/plant) }\end{array}$ & $\begin{array}{c}\text { Root/ shoot } \\
\text { ratio }\end{array}$ & $\begin{array}{c}\text { Resistance } \\
\text { coefficient }\end{array}$ \\
\hline 0 & $0.462 \pm 0.004 \mathrm{e}$ & $3.779 \pm 0.029 \mathrm{a}$ & $4.240 \pm 0.025 \mathrm{a}$ & 0.122 & 1.000 \\
\hline 25 & $0.480 \pm 0.004 \mathrm{~d}$ & $2.579 \pm 0.021 \mathrm{~b}$ & $3.059 \pm 0.025 \mathrm{~b}$ & 0.186 & 0.721 \\
\hline 50 & $0.505 \pm 0.011 \mathrm{c}$ & $2.097 \pm 0.034 \mathrm{c}$ & $2.602 \pm 0.026 \mathrm{c}$ & 0.241 & 0.614 \\
\hline 100 & $0.537 \pm 0.007 \mathrm{~b}$ & $2.019 \pm 0.020 \mathrm{~d}$ & $2.555 \pm 0.023 \mathrm{~d}$ & 0.266 & 0.603 \\
\hline 200 & $0.577 \pm 0.002 \mathrm{a}$ & $1.863 \pm 0.013 \mathrm{e}$ & $2.440 \pm 0.010 \mathrm{e}$ & 0.310 & 0.575 \\
\hline
\end{tabular}

Photosynthetic Pigment Content of S. media. PP333 increased the contents of chlorophyll $a$, chlorophyll $b$, total chlorophyll and carotenoid (Table 2). With the increase of PP333 concentrations, the contents of chlorophyll $a$, chlorophyll $b$, total chlorophyll and carotenoid increased when the dose of PP333 was not more than $100 \mathrm{mg} / \mathrm{L}$, and decreased when the dose of PP333 was more than 100 $\mathrm{mg} / \mathrm{L}$. For the chlorophyll a/b, PP333 decreased the chlorophyll a/b of $S$. Media, and had the trend of decreasing with the increase of PP333 concentrations (Table 2).

Antioxidant Enzyme Activity of $\boldsymbol{S}$. media. PP333 enhanced the antioxidant enzyme activity of $S$. media (Table 3). So, PP333 could improve the resistance of S. media to Cd. With the increase of PP333 concentrations, the soluble protein content of $S$. media increased when the dose of PP333 was not more than $50 \mathrm{mg} / \mathrm{L}$, and decreased when the dose of PP333 was higher than $50 \mathrm{mg} / \mathrm{L}$ (Table 3). The soluble sugar content in shoots of $S$. media decreased by $16.01 \%(p<0.05), 12.49 \%(p<$ $0.05)$ and $12.46 \%(p<0.05)$ at 25,50 and $100 \mathrm{mg} / \mathrm{L} \mathrm{PP333}$, and increased by $4.59 \%(p>0.05)$ at 200 $\mathrm{mg} / \mathrm{L}$ PP333. 
Cd Content in S. media. When applied PP333 on S. media, the low concentrations of PP333 (25 and $50 \mathrm{mg} / \mathrm{L}$ ) increased the Cd content in roots of S. media, and high concentrations of PP333 (100 and $200 \mathrm{mg} / \mathrm{L}$ ) decreased that (Table 4). For the shoots of $S$. media, the Cd content in shoots increased when applied the treatment of PP333. The Cd content in shoots increased by $4.22 \%(p<0.05), 8.97 \%$ $(p<0.05), 17.68 \%(p<0.05)$ and $14.59 \%(p<0.05)$ at 25, 50, 100 and $200 \mathrm{mg} / \mathrm{L} \mathrm{PP333}$ respectively, compared with the control. When the dose of PP333 was $100 \mathrm{mg} / \mathrm{L}$, the Cd content in shoots got the maxmium of $50.25 \mathrm{mg} / \mathrm{kg}$. With the increase of PP333 concentrations, the BCF of roots increased when the dose of PP333 was not more than $50 \mathrm{mg} / \mathrm{L}$, and decreased from the dose of $50 \mathrm{mg} / \mathrm{L}$ to 200

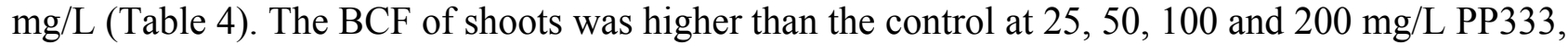
and the maxmium was at the dose of $100 \mathrm{mg} / \mathrm{L}$. All of the PP333 treatments improved the TF, and the maxmium was at the dose of $100 \mathrm{mg} / \mathrm{L}$ (Table 4). So, PP333 could promote the Cd transport from roots to shoots.

Table 2 Effects of PP333 on photosynthetic pigment content of S. media

\begin{tabular}{|c|l|l|c|c|c|}
\hline $\begin{array}{c}\text { PP333 } \\
\text { concentration } \\
(\mathrm{mg} / \mathrm{L})\end{array}$ & $\begin{array}{c}\text { Chlorophyll } a \\
(\mathrm{mg} / \mathrm{g})\end{array}$ & $\begin{array}{c}\text { Chlorophyll } b \\
(\mathrm{mg} / \mathrm{g})\end{array}$ & $\begin{array}{c}\text { Total } \\
\text { chlorophyll } \\
(\mathrm{mg} / \mathrm{g})\end{array}$ & $\begin{array}{c}\text { Chlorophyll } \\
\mathrm{a} / \mathrm{b}\end{array}$ & $\begin{array}{c}\text { Carotenoid } \\
(\mathrm{mg} / \mathrm{g})\end{array}$ \\
\hline 0 & $1.272 \pm 0.038 \mathrm{~d}$ & $0.434 \pm 0.016 \mathrm{c}$ & $1.706 \pm 0.012 \mathrm{e}$ & 2.931 & $0.286 \pm 0.009 \mathrm{~d}$ \\
\hline 25 & $1.413 \pm 0.009 \mathrm{bc}$ & $0.502 \pm 0.003 \mathrm{~b}$ & $1.914 \pm 0.011 \mathrm{c}$ & 2.815 & $0.303 \pm 0.005 \mathrm{bc}$ \\
\hline 50 & $1.434 \pm 0.022 \mathrm{ab}$ & $0.512 \pm 0.021 \mathrm{ab}$ & $1.946 \pm 0.013 \mathrm{~b}$ & 2.801 & $0.316 \pm 0.003 \mathrm{ab}$ \\
\hline 100 & $1.477 \pm 0.039 \mathrm{a}$ & $0.538 \pm 0.023 \mathrm{a}$ & $2.015 \pm 0.012 \mathrm{a}$ & 2.745 & $0.323 \pm 0.013 \mathrm{a}$ \\
\hline 200 & $1.366 \pm 0.017 \mathrm{c}$ & $0.486 \pm 0.008 \mathrm{~b}$ & $1.852 \pm 0.014 \mathrm{~d}$ & 2.811 & $0.297 \pm 0.009 \mathrm{~cd}$ \\
\hline
\end{tabular}

Table 3 Effects of PP333 on antioxidant enzyme activity of $S$. media

\begin{tabular}{|c|l|l|l|l|c|}
\hline $\begin{array}{c}\text { PP333 } \\
\text { concentratio } \\
\mathrm{n} \\
(\mathrm{mg} / \mathrm{L})\end{array}$ & $\begin{array}{c}\text { SOD activity } \\
(\mathrm{U} / \mathrm{g})\end{array}$ & $\begin{array}{c}\text { POD activity } \\
(\mathrm{U} / \mathrm{g})\end{array}$ & $\begin{array}{c}\text { CAT activity } \\
(\mathrm{U} / \mathrm{g})\end{array}$ & $\begin{array}{c}\text { Soluble protein } \\
\text { content } \\
(\mathrm{mg} / \mathrm{g})\end{array}$ & $\begin{array}{c}\text { Soluble sugar } \\
\text { content } \\
(\%)\end{array}$ \\
\hline 0 & $123.27 \pm 1.94 \mathrm{~d}$ & $833.10 \pm 5.14 \mathrm{c}$ & $16.17 \pm 0.35 \mathrm{~d}$ & $13.81 \pm 0.17 \mathrm{~d}$ & $8.358 \pm 0.617 \mathrm{a}$ \\
\hline 25 & $124.85 \pm 0.21 \mathrm{~d}$ & $1064.83 \pm 10.41 \mathrm{a}$ & $17.11 \pm 0.38 \mathrm{c}$ & $18.47 \pm 0.46 \mathrm{~b}$ & $7.020 \pm 0.116 \mathrm{~b}$ \\
\hline 50 & $138.60 \pm 1.35 \mathrm{~b}$ & $1072.28 \pm 5.37 \mathrm{a}$ & $20.62 \pm 0.01 \mathrm{a}$ & $20.22 \pm 0.78 \mathrm{a}$ & $7.314 \pm 0.097 \mathrm{~b}$ \\
\hline 100 & $155.87 \pm 4.00 \mathrm{a}$ & $989.45 \pm 3.69 \mathrm{~b}$ & $19.07 \pm 0.93 \mathrm{~b}$ & $16.61 \pm 0.51 \mathrm{c}$ & $7.317 \pm 0.210 \mathrm{~b}$ \\
\hline 200 & $131.65 \pm 3.78 \mathrm{c}$ & $980.93 \pm 8.65 \mathrm{~b}$ & $18.50 \pm 0.19 \mathrm{~b}$ & $13.91 \pm 0.27 \mathrm{~d}$ & $8.742 \pm 0.370 \mathrm{a}$ \\
\hline
\end{tabular}

Table 4 Effects of PP333 on cadmium content in $S$. media

\begin{tabular}{|c|c|c|c|c|c|}
\hline $\begin{array}{c}\text { PP333 concentration } \\
(\mathrm{mg} / \mathrm{L})\end{array}$ & $\begin{array}{c}\text { Roots } \\
(\mathrm{mg} / \mathrm{kg})\end{array}$ & $\begin{array}{c}\text { Shoots } \\
(\mathrm{mg} / \mathrm{kg})\end{array}$ & $\begin{array}{c}\text { BCF of } \\
\text { roots }\end{array}$ & $\begin{array}{c}\text { BCF of } \\
\text { shoots }\end{array}$ & TF \\
\hline 0 & $138.79 \pm 0.03 \mathrm{~b}$ & $42.70 \pm 0.02 \mathrm{e}$ & 5.55 & 1.71 & 0.308 \\
\hline 25 & $140.38 \pm 1.60 \mathrm{~b}$ & $44.50 \pm 0.64 \mathrm{~d}$ & 5.62 & 1.78 & 0.317 \\
\hline 50 & $148.48 \pm 0.72 \mathrm{a}$ & $46.53 \pm 0.54 \mathrm{c}$ & 5.94 & 1.86 & 0.313 \\
\hline 100 & $125.84 \pm 1.25 \mathrm{c}$ & $50.25 \pm 0.22 \mathrm{a}$ & 5.03 & 2.01 & 0.399 \\
\hline 200 & $124.83 \pm 1.20 \mathrm{c}$ & $48.93 \pm 0.65 \mathrm{~b}$ & 4.99 & 1.96 & 0.392 \\
\hline
\end{tabular}

Cd Accumulation of $\boldsymbol{S}$. media. When applied PP333 on S. media, the Cd accumulation amount of roots was higher than the control (Table 5), which was benefit to the improve the phytoremediation ability of $S$. media. The Cd accumulation amount of roots increased by $5.09 \%(p<0.05), 17.06 \%(p<$ $0.05), 5.40 \%(p<0.05)$ and $12.35 \%(p<0.05)$ at $25,50,100$ and $200 \mathrm{mg} / \mathrm{L}$ PP333 respectively, compared with the control. However, the treatment of PP333 decreased the Cd accumulation amount of shoots, which decreased by $28.86 \%(p<0.05), 39.53 \%(p<0.05), 37.13 \%(p<0.05)$ and $43.60 \%$ $(p<0.05)$ at 25, 50, 100 and $200 \mathrm{mg} / \mathrm{L}$ PP333 respectively, compared with the control. For the whole plants, the treatment of PP333 decreased the $\mathrm{Cd}$ accumulation amount of whole plants compared with the control. The treatment of PP333 also reduced the TAF (Table 5). Therefore, PP333 could not improve the phytoremediation ability of $S$. media. 
Table 5 Effects of PP333 on cadmium accumulation in S. media

\begin{tabular}{|c|c|c|c|c|}
\hline $\begin{array}{c}\text { PP333 concentration } \\
(\mathrm{mg} / \mathrm{L})\end{array}$ & $\begin{array}{c}\text { Roots } \\
(\mu \mathrm{g} / \mathrm{plant})\end{array}$ & $\begin{array}{c}\text { Shoots } \\
(\mu \mathrm{g} / \mathrm{plant})\end{array}$ & $\begin{array}{c}\text { Whole plants } \\
(\mu \mathrm{g} / \mathrm{plant})\end{array}$ & TAF \\
\hline 0 & $64.05 \pm 0.48 \mathrm{~d}$ & $161.34 \pm 3.40 \mathrm{a}$ & $225.39 \pm 2.93 \mathrm{a}$ & 2.52 \\
\hline 25 & $67.31 \pm 1.26 \mathrm{c}$ & $114.77 \pm 2.45 \mathrm{~b}$ & $182.08 \pm 4.70 \mathrm{~b}$ & 1.70 \\
\hline 50 & $74.98 \pm 1.07 \mathrm{a}$ & $97.57 \pm 2.74 \mathrm{c}$ & $172.56 \pm 3.67 \mathrm{c}$ & 1.30 \\
\hline 100 & $67.51 \pm 1.46 \mathrm{c}$ & $101.43 \pm 0.44 \mathrm{c}$ & $168.94 \pm 1.90 \mathrm{~cd}$ & 1.50 \\
\hline 200 & $71.96 \pm 0.56 \mathrm{~b}$ & $91.16 \pm 1.37 \mathrm{~d}$ & $163.12 \pm 1.93 \mathrm{~d}$ & 1.27 \\
\hline
\end{tabular}

\section{Conclusions}

Applied PP333 on S. media, the root biomass increased with the increase of PP333 concentrations, but the shoot biomass and total biomass decreased. PP333 enhanced the photosynthetic pigment content, antioxidant enzyme activity and soluble protein content of $S$. media, and decreased the soluble sugar content in shoots of $S$. media. The low concentrations of PP333 (25 and $50 \mathrm{mg} / \mathrm{L})$ increased the $\mathrm{Cd}$ content in roots of $S$. media, and high concentrations of PP333 (100 and $200 \mathrm{mg} / \mathrm{L}$ ) decreased that. The $\mathrm{Cd}$ content in shoots increased when applied the treatment of PP333. When applied PP333 on S. media, the Cd accumulation amount of roots was higher than the control, and the $\mathrm{Cd}$ accumulation amount of shoots and whole plants were lower than the control. Therefore, PP333 could not improve the phytoremediation ability of $S$. media.

\section{References}

[1] W.W.Zeng, Y.X. Li, L.L. Di, X.K. Sun and Y.Q. Li: Journal of Anhui Agricultural Sciences Vol. 40 (2012), p. 8063.

[2] L.B. Zhu, J.W. Li, M.R. Li, F.D. Zhan, J.X. Wang and Y.M. He: Guizhou Agricultural Sciences Vol. 42 (2014), p. 29.

[3] D. Zhao: Role of Paclobutrazol (PP333) in alleviating copper toxicity in sweet sorghum seedlings (thesis of master degree, Najing Agricultural University, Nanjing, China 2009).

[4] H.X. Xia, Y.J. Ding and Q.H. Zhu: Guizhou Agricultural Sciences Vol. 39(2011), p. 70.

[5] L.J. Lin, B. Ning, M.A. Liao, H.J. Lan and H. Liang: Ecology and Environmental Sciences Vol 23 (2014), p. 673.

[6] L.J. Lin, M.A. Liao, L.Y. Mei, J. Liu, J. Cheng, L. Luo and Y.J. Liu: Environmental Progress \& Sustainable Energy Vol 33 (2014), p. 1251.

[7] Z.B. Hao, J. Cang and Z. Xu: Plant Physiology Experiment (Harbin Institute of Technology Press, Harbin, China 2004).

[8] Z. Lukačová Kuliková and A. Lux: Bulletin of Environmental Contamination and Toxicology Vol 85 (2010), p. 243.

[9] Y.D. Zhao, Y.Z. Pan, B.Y. Liu, H. Yang, Y. Hou, J. F. Zhang and L. Cai: Journal of Agro-Environment Science Vol 31 (2012), p. 48.

[10]X. F. Zhang, H. P. Xia, Z. A. Li, P. Zhuang and B. Gao: Journal of Hazardous Materials Vol 189 (2011), p. 414.

[11]F. Rastmanesh, F. Moore and B. Keshavarzi: Bulletin of Environmental Contamination and Toxicology Vol 85 (2010), p. 515.

[12]F.H. Nie: Ecology and Environment Vol 14 (2005), p. 136. 